\title{
Correction to: Inclusion of GPS clock estimates for satellites Sentinel-3A/3B in DORIS geodetic solutions
}

\author{
Petr Štěpánek ${ }^{1}\left[\right.$ (D) Urs Hugentobler ${ }^{2}\left[\right.$ Vratislav Filler $^{1} \cdot$ Bingbing Duan $^{2}[$
}

Published online: 23 October 2021

○) Springer-Verlag GmbH Germany, part of Springer Nature 2021

\section{Correction to: Journal of Geodesy (2020) 94:116 https://doi.org/10.1007/s00190-020-01428-x}

After publication in vol 94 Issue 12, it was noticed that the author names were incorrectly given as Štepánek Petr, Duan Bingbing, Filler Vratislav, Hugentobler Urs. The correct author names are Petr Štěpánek, Urs Hugentobler, Vratislav Filler, Bingbing Duan. Furthermore, their ORCID iDs were added.

The original article can be found online at https://doi.org/10.1007/s00 190-020-01428-x.

$凶$ Petr Štěpánek petr.stepanek@pecny.cz

1 Research Institute of Geodesy, Topography and Cartography, Zdiby, Czech Republic

2 Institute for Astronomical and Physical Geodesy, Technical University of Munich, Munich, Germany 